\title{
Border Economy: Issues and Problems Faced by Traders in The Rantau Panjang Duty-free Zone
}

\author{
Fauzi Hussin \\ Economics Department, School of Economics, Finance and Banking, Universiti Utara \\ Malaysia, Malaysia \\ Email: fauzi@uum.edu.my \\ Norehan Abdullah \\ Economics Department, School of Economics, Finance and Banking, Universiti Utara \\ Malaysia, Malaysia \\ Email: norehan@uum.edu.my
}

\begin{abstract}
Selamah Maamor
Muamalat and Islamic Finance Department, Islamic Business School, Universiti Utara

Malaysia, Malaysia

Email: selamahm@uum.edu.my

Hussin Abdullah

Economics Department, School of Economics, Finance and Banking, Universiti Utara

Malaysia, Malaysia

Email: Hussin2141@uum.edu.my
\end{abstract}

Accepted: July 07, 2012 Published: July 31, 2012

Doi:10.5296/jsr.v3i2.2175 URL: http://dx.doi.org/10.5296/jsr.v3i2.2175

\begin{abstract}
Rantau Panjang Duty-free Zone is located between the state of Kelantan (Malaysia) and Golok Town (Thailand). This paper seeks to identify issues and problems faced by traders in the Rantau Panjang Duty-free Zone. In addition, the study also aims to identify socio-demographic characteristics of the traders, especially in terms of their citizenship status, sources of supply, ownership status of business premises, sources of capital and income. Data collection using questionnaire, conducted via face to face interviews with 52 traders as respondents, indicates that the main issue facing local traders is competing with traders from Thailand who rent business premises owned by local citizens. About $77 \%$ of the premises were rented from the original owner without the knowledge of the authorities. The issue of dual citizenships is still an unanswered question when $48 \%$ or the respondents refused to
\end{abstract}


answer the relevant question. The weakness of enforcement along the Sungai Golok and Rantau Panjang Duty-free Zone causes smuggling of goods where most of the smuggled goods are traded in the business premises in the Duty-free Zone. This study also found that about $70 \%$ of the traders' sources of supply are from Thailand, brought-in either legally or illegally. There are a total of $73 \%$ of women traders, and about $82 \%$ of the capital for business come from own savings or family assistance.

Keywords: Border Economy, Rantau Panjang Duty-free Zone. Malaysia-Thailand Border.

\section{Introduction}

Rantau Panjang Duty-free Zone has unique features and is different compared to other duty-free zones in Malaysia. Prior to being declared as a duty-free zone by the government, the area is a typical village which possesses facilities such as schools, mosques, clinics and other basic amenities. After being declared as a duty-free zone, the boundary include all original dwellings in the zone and its facilities.

According to the information obtained from the Pasir Mas District Council (Rantau Panjang branch), in 2010, there were 1,887 traders in duty-free zone, including some traders outside the zone, under the administration of the Pasir Mas District Council. Based on the records, there were 2,153 homes, three schools (primary and secondary), a clinic and a market in this duty-free zone with an estimated population of about 30,800 people.

There are several types of trader outlets in the duty free zone such as the District Council-owned shops which are rented to the traders, privately-owned shops, traders in the area known as the 'Horse Barn Marketplace' and traders who use carts. 'Horse Barn Marketplace' is a temporary business site provided by the District Council for rentals to the traders. However, beginning in 2012, all traders in the 'Horse Barn Marketplace' will be directed to move to a three-storey building built close to the the existing business site. However, most of the traders are not willing to move because the rental rates are much higher, besides other concerns such as the loss of their regular customers.

Every private business premise (including cart traders) are imposed different types of license and tax. For example, stalls selling food and drinks are imposed a license fee of RM50 and a garbage collection tax of RM60 (depending on outlet size), privately-owned shops have to pay a license fee of RM300 (including advertisement board), traders at the 'Horse Barn Marketplace' have to pay rentals of between RM12 - RM165 and another RM60 for garbage collection. Rental as low as RM12 is charged for a small premise without a roof whereas RM165 is charged for a bigger premise with a roof.

Three border gates into the duty free zone are controlled by customs officers. Immigration officers are not placed at the border checkpoints because all the border gates are located in the Rantau Panjang District (Malaysia territory). All matters related to immigration are 
carried out at the Sungai Golok - Rantau Panjang bridge linking the two countries. All matters in the duty free zone area are under the administration and enforcement of the Pasir Mas District Council (Rantau Panjang branch). Meanwhile, the areas has no border fence but are only separated from Thailand by the Sungai Golok waters whose width are only around 100 meters.

This paper seeks to identify issues and problems faced by traders in the Rantau Panjang Duty Free Zone and problems related to the enforcement along the waters of Sungai Golok - Duty free Zone. In addition, this paper will discuss the socioeconomic profile of the traders, particularly in terms of traders characteristics, ownership status of premises, sources of supply, sources of capital and total income of the traders.

\section{Literature Review}

Several studies by previous researchers related to smugglers and the effects on the border economy are discussed in this paper. The study by Schoenberger and Turner (2008) examine how cross-border trading network that is practiced by the people of ethnic minorities and ethnic majority Kinh in the highlands of north west Vietnam with residents in the southwest China. They found that through this trade activities, access to the boundary between the different components of society are complex, not only in terms of domestic policy but also in terms of the relationship between different ethnic groups to seize economic opportunities.

Bruns et al. (2011) give their views based on empirical evidence in post-socialist countries on why small-scale, cross-border smuggling and trading activities occur. Cross-border economic activities can take place because it has been accepted by the community even though such activities are against the law.

Small-scale trade across borders mostly involved women aged between 20 to 40 years. This is due to the increasing need for them to possess a bigger economic power in making decisions which may give impact on their every day lives (KOIS, 2011).

Globalization of the world economy is characterized by increased cross border activities where several authors argue that state borders now function as porous membranes to facilitate economic and social interactions across borders (Dicken, 2000, Evans et al, 2000). However, at the same time, contemporary borders are important symbols of state control over territories and population movements. In fact, the globalization process, market liberalization and the opening of borders to trade are often associated with the assertion of government control at physical border sites (Andreas, 2000; Kusakabe, 2004; Papademetriou and Waller Meyers, 2001; Walker, 1999).

States have always been key determinants for cross-border flows of goods and people, disputing the claim that we are living in a borderless world (Hirst and Thompson, 1995; 
Ohmae, 1990). State borders restrict the territory in which a state maintains sovereignty, acts as 'inspection agents' to control what can be brought in legally and under certain conditions between the political jurisdiction borders. In this context, they argue for the need to pay more attention to the borders in relation to various current issues, including international political relations, cross-border regions, authority of governments, cultural landscape, and the informal economy (Donnan et al. And Wilson, 1994, 1999; Pavlakovich-Kochi et al, 2004; Newman, 2006).

Morehouse et al. (2004), argue that legislative field limits rarely represent the reality of boundary, in fact, regional border zone and cultural landscape are seen from different perspectives. Border identity is formed by the interaction of people with the border, transactions among themselves and between people in different boundaries. In addition, people at the border are often thinking of pragmatic ways to negotiate border limits and state policies, thus government efforts to establish political and economic parameters for cross border interactions often cannot totally control every day practices that occur. As proposed by Donnan and Wilson (1994) in the context of Southeast Asia, the people and institutions at the local level that borders with each other have always been a part of a complex relationship with ethnic groups and other races either within or outside their own countries.

Martin and Panagariya (1983) find that more stringent law enforcement against smuggling will increase the per unit cost of goods and reduce the quantity of smuggled imported goods. The intensification of anti-smuggling enforcement legislation will increase the actual cost per unit of smuggled goods and domestic prices of imports, but lowering the absolute quantity and the proportion of illegal imports from total imports. However, their model does not explain the effect of smuggling on social welfare.

\section{Methodology}

This survey uses a questionnaire to gather data from traders at the Rantau Panjang Duty-free Zone. Face-to-face interviews were carried out on 52 respondents. There are several types of trader outlets in the duty free zone such as the District Council-owned shops which are rented to traders, privately-owned shops, traders in the area known as the 'Horse Barn Marketplace' and traders who use carts. Most of the respondents in this study are traders in the 'Horse Barn site' as traders here sell various types of good either local products or imported goods from Thailand. Imported goods are categorized as goods brought in legally through customs and immigration at the Sungai Golok- Rantau Panjang bridge and smuggled goods brought in by boats across the Sungai golok along the Sungai Golok - Rantau Panjang Free-duty Zone.

Questionnaire for traders at the Rantau Panjang Duty-free Zone is divided into three sections, Section A contains current business-related information, Section B is related to the demographic information of respondents, and Section $\mathrm{C}$ is related to the demographic 
information of the respondents' spouse. The analysis of the study uses descriptive method.

\section{Findings}

There are two issues and problems discussed in the paper. First, the issue of competition between local traders with traders from Thailand who rent premises in the duty-free zone. Second, the issue of enforcement along the waters of Sungai Golok and Rantau Panjang Duty-free Zone.

The waters along Sungai Golok which is about 29.9 miles long starting from Pengkalan Kubor, Tumpat to Rantau Panjang, Kelantan is the main border that separates the the state of Kelantan (Malaysia) with the Territory of Narathiwat, Thailand. The enforcement aspect at the boundary shows many difficulties faced by security enforcement agencies who worked patrolling the border of the two countries. Even though there are several security enforcement agencies that patrol the border, such as the Anti-Smuggling Unit (UPP), Customs Unit (enforcement), and the Armed Forces (replacing PGA duties starting November 2010) to control the entry and exit of illegal goods through the waters of Sungai Golok, the movement of illegal goods still goes on unabated.

This is due to too many illegal jetties built along the boundary waters of Pengkalan Kubor, Tumpat to Rantau Panjang Duty-free Zone that can be used for boat routes which carry goods illegally either from the town of Golok (Thailand) to the Rantau Panjang Duty-free Zone or vice versa. For example, there are more than 130 bases for the illegal smuggling of goods along the border, in fact there are dozens of illegal base along the waters of Sungai Golok and Rantau Panjang Duty-free area alone.

The main goods which are frequently brought into Thailand via these illegal bases along the duty-free zone are sugar, cooking oil and other essentials. Meanwhile, even more goods from Thailand are illegally brought into the duty-free zone through the waters of Sungai Golok. They include rice, imitation branded- clothing, fruits \& vegetables, kitchenwares and others.

There are many complaints from local traders in the duty-free zone about the bureaucracy at the local authority level, which results in foreign traders being able to do business in the zone. The presence of foreign traders causes price wars between them and the local traders. Ironically, how do these foreign traders get their business licenses since the requirement for getting a license is for those who possess an identity card. Local traders experience problems when they are forced to vacate their rented stalls when they are unable to pay high rents which do not commensurate with their daily incomes. Problems also occur when local traders are forced to move their stall to under the trees when foreign traders' stalls block customers' view to the formers' stalls. This area does not provide business opportunities for 
local traders as it is clearly monopolized by foreign traders. From another angle, the management problem in the duty-free zone is in terms of the haphazard arrangement of the stalls as well as the problem of unsystematic maintenance of garbage which makes the area seems dirty and spoils the view, especially for tourists.

\subsection{Profile of Respondents}

Table 1 shows that 75 percent of the respondents have been in business in the duty-free zone between 1991 and 2010, while 25 percent of the respondents started their business in duty-free zone before 1991. About 42.3 percent of the respondents in the duty-free zone are between the age of 31 and 40 years, while 21.2 percent of the respondents are between the age of 41 and 50 years old. Finally, another 19 percent of the respondents are aged between 51 and 60 years old.

The results show that the highest number of respondents, about 77 percent, come from several districts in the state of Kelantan, Malaysia, followed by 21 percent who come from Thailand. Most of the respondents, or 83 percent, who are involved as a trader in the duty-free zone are married. The remaining 8 percent who are involved as a trader in duty-free zone are unmarried.

Regarding the nationality of the traders' spouse, about 71 percent have spouse among the locals, whereas 6 percent have spouse of foreign citizens who come to work in duty-free zone. In addition, 4 percent of the traders' spouse have permanent resident or citizenship status.

Question then arises when the traders were asked whether or not they have dual nationalities, since only 3.8 percent of the respondents admitted to having dual nationalities, whereas another 48 percent refused or avoid answering this question.

\section{Table 1: Characteristics of respondents}

\begin{tabular}{|l|l|l|l|}
\hline \multicolumn{2}{|l|}{ Variables } & Frequency & Percent \\
\hline \multirow{4}{*}{$\begin{array}{l}\text { Year started in } \\
\text { business }\end{array}$} & $<1980$ & 6 & 11.5 \\
\cline { 2 - 4 } & $1981-1990$ & 7 & 13.5 \\
\cline { 2 - 4 } & $1991-2000$ & 21 & 40.4 \\
\cline { 2 - 4 } & $2001-2010$ & 18 & 34.6 \\
\hline \multirow{4}{*}{ Age } & $<20$ yrs & 0 & 0 \\
\cline { 2 - 4 } & $20-30 \mathrm{yrs}$ & 7 & 13.5 \\
\cline { 2 - 4 } & $31-40 \mathrm{yrs}$ & 22 & 21.2 \\
\cline { 2 - 4 } & $41-50 \mathrm{yrs}$ & 10 & 42.3 \\
\cline { 2 - 4 } & $51-60 \mathrm{yrs}$ & & 19.2 \\
\hline
\end{tabular}




\begin{tabular}{|l|l|l|l|}
\hline \multirow{4}{*}{$\begin{array}{l}\text { Region } \\
\text { Country }\end{array}$} & 60 yrs > & 2 & 3.8 \\
\cline { 2 - 4 } & Rantau Panjang District & 25 & 48 \\
\hline \multirow{4}{*}{$\begin{array}{l}\text { Other districts in the state } \\
\text { of Kelantan }\end{array}$} & 15 & 29 \\
\cline { 2 - 4 } & Thailand & 11 & 21 \\
\cline { 2 - 4 } & Other states in Malaysia & 1 & 2 \\
\hline \multirow{4}{*}{$\begin{array}{l}\text { Nationality status of } \\
\text { spouse }\end{array}$} & Unmarried & 4 & 7.7 \\
\cline { 2 - 4 } & Married & 43 & 82.7 \\
\cline { 2 - 4 } & Divorced / widow & 5 & 9.6 \\
\cline { 2 - 4 } & not applicable & 10 & 19.2 \\
\cline { 2 - 4 } & local people & 37 & 71.2 \\
\cline { 2 - 4 } $\begin{array}{l}\text { You have dual } \\
\text { nationalities? }\end{array}$ & Permanent resident status & 1 & 1.9 \\
\cline { 2 - 4 } & Foreigners - working & 3 & 3.8 \\
\cline { 2 - 4 } & Yes & & $48.1 \%$ \\
\cline { 2 - 4 } & No response & & $48.1 \%$ \\
\hline & & & \\
\hline
\end{tabular}

\subsection{Business Infromation}

Most of the respondents, about 54 percent, are involved in clothing, ornament or craft business. This is followed by 15.4 percent who are in sundry shop business. In addition, hawkers who sell food and beverages on the move made up about 10 percent of the respondents interviewed.

Most business premises are operated as sole proprietorship (85\%), compared to the family partnership (12\%). Most businesses are registered or licensed premises (92.3\%). Problem arises when most of the business premises are leased to other traders (77\%), especially traders from Thailand, compared to only 23 per cent which are run by the owners themselves.

The main source of supply of goods for business, about 70 percent, are from Thailand, compared to only about 30 percent from Malaysia. Most traders get involved in a particular business because of opportunity, as well as the business is easily run or operated.

Table 2: Business Information

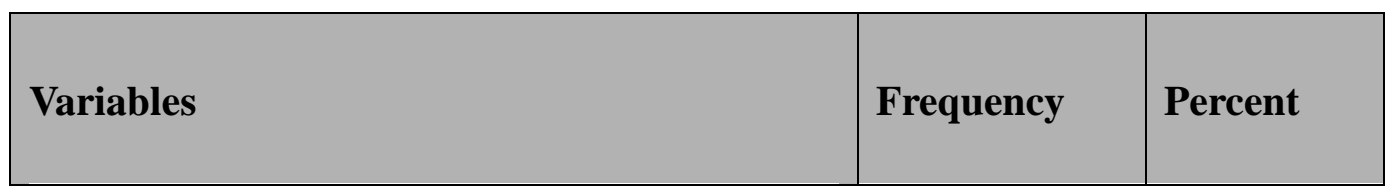




\begin{tabular}{|c|c|c|c|}
\hline \multirow{6}{*}{$\begin{array}{ll}\text { Type } & \text { of } \\
\text { Business }\end{array}$} & $\begin{array}{l}\text { Food/drinks hawker on the } \\
\text { move }\end{array}$ & 5 & 9.6 \\
\hline & Food Stall & 1 & 1.9 \\
\hline & Sundry Shop & 8 & 15.4 \\
\hline & $\begin{array}{l}\text { Clothing/Ornament/Handicraft } \\
\text { Shop }\end{array}$ & 28 & 53.8 \\
\hline & Hardward Shop & 1 & 1.9 \\
\hline & Others & 9 & 17.3 \\
\hline \multirow{2}{*}{\begin{tabular}{ll|} 
Ownership \\
Status \\
Premises
\end{tabular}} & Owned & 12 & 23.1 \\
\hline & Rented & 40 & 76.9 \\
\hline \multirow{3}{*}{$\begin{array}{l}\text { Type of } \\
\text { Ownership }\end{array}$} & Propreitorship & 44 & 84.6 \\
\hline & Family Partnership & 6 & 11.5 \\
\hline & Non-family Partnership & 2 & 3.8 \\
\hline \multirow{2}{*}{$\begin{array}{l}\text { Company } \\
\text { Registration } \\
\text { Status }\end{array}$} & $\begin{array}{l}\text { Registered Company/Business } \\
\text { (Licensed) }\end{array}$ & 48 & 92.3 \\
\hline & $\begin{array}{l}\text { Unregisted } \\
\text { Company/Business }\end{array}$ & 4 & 7.7 \\
\hline \multirow{3}{*}{$\begin{array}{l}\text { Source } \\
\text { Supply }\end{array}$} & Sources in Thailand & & $70 \%$ \\
\hline & Sources in Malaysia & & $30 \%$ \\
\hline & Sources in Other Countries & & $0 \%$ \\
\hline \multirow{5}{*}{$\begin{array}{l}\text { Reason for } \\
\text { Choosing } \\
\text { Particular } \\
\text { Business }\end{array}$} & Experience in the field & & $18.4 \%$ \\
\hline & Have the qualification & & $1.3 \%$ \\
\hline & Family encouragement & & $21.2 \%$ \\
\hline & Opportunity \& easy to run & & $43.4 \%$ \\
\hline & Others & & $15.8 \%$ \\
\hline \multirow{3}{*}{$\begin{array}{l}\text { Type of } \\
\text { Customer }\end{array}$} & Final user & 83 & $55.3 \%$ \\
\hline & Retailer & 9 & $6.0 \%$ \\
\hline & Final user \& retailer & 58 & $38.7 \%$ \\
\hline
\end{tabular}

Table 3 indicates the amount and sources of capital to start a business. A total of 52 percent of the traders started with a capital of less than RM2, 000 compared to 31 percent who started a business with a capital of RM2, 001 - RM10, 000. However, a total of 17 percent of the traders started with a capital of more than RM10, 000. Most traders, or about 82 percent, raised the capital to start their business from their own savings or family assistance, compared to only about 3.3 percent who obtained loans from banks.

Most traders, about 44 percent, get a net profit of less than RM2, 000 per month, compared to 35 percent who get between RM1,200 - RM3,600 per month. However, about 22 percent earn more than RM3,600 per month. 
Table 3: Capital and Income of Traders

\begin{tabular}{|c|c|c|c|}
\hline \multicolumn{2}{|l|}{ Variables } & \multirow{2}{*}{$\begin{array}{l}\text { Frequency } \\
27\end{array}$} & \multirow{2}{*}{$\begin{array}{l}\text { Percent } \\
51.9 \\
\end{array}$} \\
\hline \multirow{6}{*}{$\begin{array}{l}\text { Total Initial } \\
\text { Capital }\end{array}$} & $<\quad 2,000$ & & \\
\hline & $2,001-4,000$ & 5 & 9.6 \\
\hline & $4,001-6,000$ & 5 & 9.6 \\
\hline & $6,001-8,000$ & 1 & 1.9 \\
\hline & $8,001-10,000$ & 5 & 9.6 \\
\hline & $>10,000$ & 9 & 17.3 \\
\hline \multirow{5}{*}{$\begin{array}{l}\text { Source of } \\
\text { Capital }\end{array}$} & Own saving/family & & $82 \%$ \\
\hline & Loan from friend/s & & $4.9 \%$ \\
\hline & Loan from bank/s & & $3.3 \%$ \\
\hline & Loan from cooperative & & $8.2 \%$ \\
\hline & $\begin{array}{l}\text { Assistance from other } \\
\text { agencies }\end{array}$ & & $1.6 \%$ \\
\hline \multirow{8}{*}{$\begin{array}{l}\text { Average Daily } \\
\text { Income }\end{array}$} & $<200$ & 16 & 30.8 \\
\hline & $201-400$ & 11 & 21.2 \\
\hline & $401-600$ & 8 & 15.4 \\
\hline & $601-800$ & 4 & 7.7 \\
\hline & $801-1,000$ & 3 & 5.8 \\
\hline & $1,001-1,200$ & 6 & 11.5 \\
\hline & $1,201-1,400$ & 2 & 3.8 \\
\hline & $>1,400$ & 2 & 3.8 \\
\hline \multirow{5}{*}{$\begin{array}{l}\text { Average } \\
\text { Monthly } \\
\text { Profit * }\end{array}$} & $<1,200$ & 23 & 44.2 \\
\hline & $1,200-2,400$ & 9 & 17.3 \\
\hline & $2,401-3,600$ & 9 & 17.3 \\
\hline & $3,601-7,200$ & 7 & 13.5 \\
\hline & $>7,200$ & 4 & 7.7 \\
\hline
\end{tabular}

*Assuming 6 workdays per week

\section{Conclusions and Discussion}

This paper seeks to identify issues and problems faced by traders and to identify the socio-demographic characteristics of traders at the Rantau Panjang Duty Free Zone, 
particularly in terms of citizenship status, sources of supply, ownership status of premises, sources of capital and income of traders. The main issue faced by traders is the competition with traders from Thailand who rented business premises owned by local citizens. Although the condition for ownership of a business premise must be a Malaysian citizen, the study shows that about 77 percent of the business premises are leased, mostly to traders from Thailand. The failure of the authorities to deal with these problems may cause more business premises to be rented to Thai traders.

The weakness of enforcement along the waters of Sungai Golok and Rantau Panjang Duty Free Zone causes smuggling of goods where most of the goods are sold at the business premises in the duty free zone. Approximately 70 percent of the sources of supply in duty-free zone are from Thailand, brought either legally or illegally into the duty free zone.

The issue of whether many traders possess dual citizenships is still unanswered as about 48 percent of the respondents refused to answer the question. Only 3.8 percent of the respondents admitted to having dual nationalities.

\section{References}

Andreas, P. (2000). Border Games: Policing the US-Mexico Divide. Ithaca, NY: Cornell University Press.

Bruns, B; Miggelbrink, J. \& Muller, K. (2011). Smuggling and Small-Scale Trade as Part of Informal Economic Practices - Empirical Findings from the Eastern External EU Border (pre-print paper), Germany: Emerald Group Publishing Limited.

Dicken, P. (2000). 'Globalization', in R.J. Johnston, D. Gregory, G. Pratt and M. Watts (eds) Dictionary of Human Geography (4th ed), pp. 315-16. Oxford: Blackwell.

Donnan, H. and T.M. Wilson (1994). 'An Anthropology of Frontiers', in H. Donnan and T.M. Wilson (eds) Border Approaches: Anthropological Perspectives on Frontiers, pp. 1-14. Lanham,

MD: University Press of America.

Donnan, H. and T.M. Wilson (1999). Borders: Frontiers of Identity, Nation and State. Oxford: Berg.

Evans, G., C. Hutton and Kuah Khun Eng (eds) (2000). Where China Meets Southeast Asia:Social and Cultural Change in the Border Regions. New York: St Martin's Press.

Hirst, P. and G. Thompson (1995). 'Globalization and the Future of the Nation State', Economy

and Society 24(3): 408-42. 
Kusakabe, K. (2004). 'Women's Work and Market Hierarchies along the Border of Lao PDR', Gender, Place, Culture 11(4): 581-94.

Martin L. and Panagariya A. (1983). Trade barriers and enforcement in an economy with endogenous smuggling, manuscript, University of Maryland.

Morehouse, B.J., V. Pavlakovich-Kochi and D. Wastl-Walter (2004a). 'Introduction: Perspectives

on Borderlands', in V. Pavlakovich-Kochi, B.J. Morehouse and D. Wastl-Walter (eds)

Newman, D. (2006). 'The Lines that Continue to Separate Us: Borders in Our "Borderless" World', Progress in Human Geography 30(2): 143-62.

Ohmae, K. (1990). The Borderless World. New York: HarperCollins.

Papademetriou, D.G. and D. Waller Meyers (2001). 'Introduction: Overview, Context and a Vision for the Future', in D.G. Papademetriou and D. Waller Meyers (eds) Caught in the Middle: Border Communities in anEra of Globalization, pp. 1-40. Washington, DC:Carnegie Endowment for International Peace.

Pavlakovich-Kochi, V., B.J. Morehouse and D. Wastl-Walter (eds) (2004). Challenged Borderlands:Transcending Political and Cultural Boundaries. Aldershot: Ashgate.

Schoenberger, L. \& Turner, S. (2008). Negotiating Remote Borderland Access: Small-Scale Trade on the Vietnam-China Border. Development and Change, 39(4), 667-696

Walker, A. (1999). The Legend of the Golden Boat: Regulation, Trade and Traders in the Borderlands of Laos, Thailand, China and Burma. Richmond, Surrey: Curzon Press. 